\title{
Vegetation and Soil Responses to Cattle Grazing Systems in the Texas Rolling Plains
}

\author{
M. KARL WOOD AND WILBERT H. BLACKBURN
}

\begin{abstract}
The influence of cattle grazing on selected vegetation and soil parameters were evaluated on a clay flat range site with shrub zonal, midgrass, and shortgrass communities in the Rolling Plains near Throckmorton, Texas. Measurements were made on one pasture of each treatment during 1977 following 4 to 20 years of grazing treatments. Heavy, continuous cattle grazing had more area occupied by the shortgrass community than midgrass community. Heavily grazed pastures were generally dominated by the shortgrass community, with midgrasses, depending on the degree of utilization, restricted to the shrub zonal community. Conversely, cattle exclosures had no shortgrass community, and deferredrotation and moderately stocked continuously grazed systems had much midgrass community with the shortgrass community occupying only $30 \%$ of the area, thus increasing range productivity. Vegetation and soil parameters within the high intensity, low frequency and heavily stocked, continuously grazed pastures tended to be similar for the midgrass and shortgrass communities, but the shrub zonal community was generally different. Vegetation and soil parameters in the midgrass community of the moderately stocked, continuously grazed treatment were generally similar to shrub zonal and different from shortgrass communities. Vegetation and soil variables in the exclosures and deferred-rotation treatments were generally similar among the midgrass and shrub zonal communities; however, they differed from the shortgrass communities.
\end{abstract}

Grazing management has been described as the heart and core of range management (Lewis 1969). It involves the selection of number and kinds of grazing animals and their distribution over the range in space and time. Grazing management affects the kinds of plants that are grazed and the frequency, time, degree, and uniformity of use. Specialized rotational grazing systems are used to vacate a portion of the range during a particular season so that vegetation may benefit from not being grazed, trampled, or otherwise disturbed (Heady 1975). Although most grazing systems have been bidirectional in purpose-improving the vegetative and edaphic resources and increasing animal production-plant ecological concepts have dominated grazing thought (Costello 1964) with much of the grazing influence being measured as vegetation responses.

Ellison (1960) concluded after an extensive literature review that successional trends are roughly proportional to grazing intensity. Retrogression is usually pronounced under severe grazing, and in some instances difficult to distinguish at light or moderate levels. Driscoll (1967) reviewed 39 studies which included vegetation analysis as a response to grazing plans. Intermittent grazing did not cause a differential response in 5 studies in comparison with continuous grazing. Grazing systems improved the range in 31 situations and decreased it in the other 8 in comparison with continuous grazing. Heady's (1975) review indicated that some studies showed

\footnotetext{
The authors are presently assuciate professor of watershed management, Department of Animal and Range Sciences, New Mexico State University, Las Cruces 88003 gement, and professor of watershed management Range Science Department, Texas A\&M University, College Station 77843.

This report is published with approval of the Director, Texas Agricultural Experiment Station, as TA-18295. The authors wish to acknowledge the cooperation of personnel from the Texas Experimental Ranch, Seymour.

Manuscript accepted October 26, 1983.
}

vegetational improvement or increased production from intermittent grazing as compared to continuous grazing, while other studies did not. Kothmann et al. (1978) compared the frequency and production of herbaceous species across several soil types near Throckmorton, Texas, and reported that vegetation responded similarly to continuous grazing and the Merrill 4-pasture, 3-herd, deferred rotation grazing system when both were moderately stocked.

Most grazing system studies have not included comparative edaphic measurements. None of the 49 studies of grazing systems between 1839 and 1966 reviewed by Hickey (1966) addressed edaphic responses. Lull (1959) concluded in his review on soil compaction that trampling by livestock compacted the upper $15 \mathrm{~cm}$ of soil and exerts pressure equivalent at least to those of heavy tractors. Laycock and Conrad (1967) found soil bulk densities of high evaluation cattle range in Utah similar to ungrazed exclosures both in early summer before grazing and in late summer after grazing. Bulk density and organic matter content were found to be similar in continuously grazed, heavily stocked and deferred rotation pastures and exclosures at the Sonora Agricultural Research Station, Texas (McGinty et al. 1979).

The objectives of this study were to compare vegetational and edaphic variables on a selected range site and soil under continuous grazing at moderate and heavy stocking rates, a high-intensity low-frequency and a deferred-rotation grazing system, and grazing exclusion.

\section{Study Area and Treatments}

Field research was conducted on the Texas Experimental Ranch, between Throckmorton and Seymour, Texas. The ranch is part of the Rolling Plains land resource area which comprises approximately 6.32 million ha of rolling topography in northwest Texas. Soils on the Texas Experimental Ranch are mostly clays and clay loams. Limestone parent materials are of the Admiral formation. Annual precipitation for Throckmorton County has averaged $624 \mathrm{~mm}$ over the past 40 years. The average frost-free period is $\mathbf{2 0 0}$ days. Peak periods for forage production are April, May, June, and September; however, if adequate rainfall occurs during July and August, forage production will continue at a high level throughout the summer.

Climax vegetation of the Rolling Plains included tall and midgrasses (Kothmann et al. 1970) but continuous heavy utilization by livestock and exclusion of natural wildfires has reduced the vegetation to primarily short and midgrasses with varying densities of woody plants. When the study was conducted in 1977 , over $70 \%$ of the ranch's herbaceous vegetation was comprised of Texas wintergrass, sideoats grama, and buffalograss. Scientific names of major species are found in Table 2 and follow Gould (1975). Honey mesquite and lotebush (Ziziphus obtusifolia) were the dominant woody species.

The ranch was established in 1957 for the purpose of investigating methods of improving the efficiency of cow-calf operations on native rangeland. Initially, grazing systems were employed and included a four-pasture, three-herd deferred rotation grazing system where each pasture was grazed for 12 months followed by 4 months of rest and a continuous grazing system with heavily stocked, moderately stocked, and lightly stocked pastures. Several 
pastures were designated as exclosures and have not been grazed by livestock since 1957. Comparisons of these grazing systems indicated that livestock production was greatest from the deferredrotation system (Kothmann et al. 1970). In the fall of 1973, an eight-pasture, one-herd high intensity, low frequency (HILF) grazing system with 17 days of grazing followed by 119 days of rest in each pasture was started for comparison with the deferred-rotation system and the continous system with stocking at moderate and heavy rates. The original stand of mesquite was chained in 1948 and sprayed aerially with $2,4,5-\mathrm{T}$ in 1964. Resprouting has occurred, but the density of 1968 was not enough to reduce forage production (Kothmann et al. 1970).

During this study, stocking rates for the deferred-rotation system; HILF system; moderately stocked, continuously grazed systems; and heavily stocked, continuously grazed system were 6.2 , $6.5,6.5$, and $4.6 \mathrm{ha} / \mathrm{au}$, respectively. The pasture which was evaluated in the HILF system was in a lightly stocked, continuously grazed system prior to 1973 . Pasture size was 237 ha for the heavily stocked, continuously grazed treatment, and 242 ha for the moderately stocked, continuously grazed pasture. The deferred rotation system consisted of 445 ha divided into 4 pastures of approximately equal size. The HILF pastures were about 120 ha each. There were 2 exclosures located on opposite sides of the study area, 8.1 and 6.9 ha in size.

The soil series studied was a Leeray clay. This series is in the fine, montmorillonitic, thermic family or Typic Chromusterts. Leeray clay is a soil series of the Clay Flat range site. This series was chosen because it occurs in all the grazing treatments in essentially equal and large (about $35 \%$ ) proportions, and accounted for $60.4 \%$ of the Clay Flat range site and $23.3 \%$ of the ranch's total area. The Leeray clay series and Clay Flat site occur extensively throughout the Rolling Plains.

\section{Methods}

Shrub zonal community was defined as the area of accumulation of litter and soil under woody plants, and midgrass and shortgrass communities were in the areas between shrub zonal communities (Fig. 1). Ten 0.7-by 0.7 -m plots were randomly located within each

\section{SHRUB ZONAL COMMUNITY}

\section{SHORT GRASS COMMUNITY}

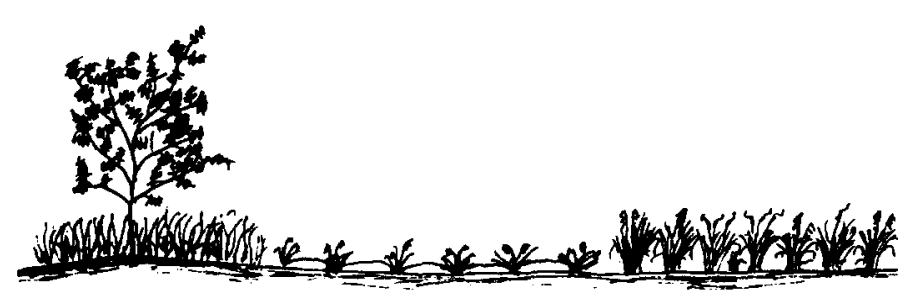

Fig. 1. Vegetation communities common on the Rolling Plains.

plant community on the Leeray clay soil series in 1 pasture of each of the different grazing treatments and 2 exclosures during late May through early July of 1977 . Measurements in the deferredrotation and HILF systems were made at the end of both a grazing period and a rest period. These sampling periods were designated treatments. The samples were taken at this time of the year because it was at the end of the peak period of forage production and the warm-season species had not begun their period of rapid growth. Percentage of the Leeray clay soil series in each treatment covered by shrub zonal, midgrass, or shortgrass communities was determined by the step point method (Levy and Madden 1933). The crown cover or aerial spread of shrubs, grasses, forbs, and ground cover of mulch were determined by ocular estimate on $0.7-$ by 0.7-m gridded sampling quadrats. Grasses, forbs, and standing dead material were harvested from each plot to a $1-\mathrm{cm}$ stubble height and mulch collected. The material was dried at $60^{\circ} \mathrm{C}$ for 1 week and weighed.

Soil was collected to 3-cm depth within each vegetation sample plot. Particle size distribution was measured by the hydrometer method (Bouyoucos 1962), water stable aggregates were determined by the wet sieve method (Black 1965), and organic matter content by the Walkley Black method (Black 1965). Bulk density was determined from an additional soil sample taken from the surface 0-to 3-cm and 5-to 8-cm depths by the core method (Black 1965).

Skewness and kurtosis tests were applied to each variable to determine the normality of data (Snedecor and Cochran 1971). If the data were not normally distributed, the common logarithmic transformation was applied before conducting analysis of variance. Within treatment variation (variation among subplots) was allocated to the residual for testing differences $(P<.95)$ among treatments (Kothmann et al. 1982). Use of within-treatment variation for the error term is an imperfect substitute for an error term derived from the variation among replications, but replications were not possible in this study. An error term based on the withintreatment variation is usually smaller than one based on replicate variation. Therefore, statistical probabilities in this study may be biased downward by an unknown amount. Also, use of the withintreatment variation as the error term gives less protection against initial differences among pastures or in errors of applying treatments than use of replicate variation as the error term. Mean separation was accomplished with Duncan's new multiple range test (Steele and Torrie 1960).

\section{Results and Discussion}

\section{Vegetation}

The mean cover percentage of shrub canopy, midgrass, and shortgrass interspace areas on the Leeray clay series for the various grazing treatments is shown in Table 1. The largest coverage of

Table 1. Mean cover (\%) of shrub zonal, midgrass interspace, and shortgrass interspace communities for various exclosures and across all subunits of grazing systems patures. 1

\begin{tabular}{lccc}
\hline & \multicolumn{3}{c}{ Plant communities } \\
\cline { 2 - 4 } & $\begin{array}{r}\text { Shrub } \\
\text { zonal }\end{array}$ & $\begin{array}{c}\text { Midgrass } \\
\text { interspace }\end{array}$ & $\begin{array}{c}\text { Shortgrass } \\
\text { interspace }\end{array}$ \\
\hline Pasture & 16.8 & 83.2 & - \\
Exclosure 1 & 8.4 & 91.6 & - \\
Deferred-rotation & 10.2 & 60.4 & 29.4 \\
HILF system & 7.6 & 48.0 & 44.4 \\
Moderately stocked, & & & \\
$\quad$ continuous system & 8.9 & 60.2 & 30.9 \\
Heavily stocked, & & & 67.0 \\
\hline continuous system & 9.8 & 23.2 & 6 \\
\hline
\end{tabular}

No shortgrass interspace was found in the exclosures.

midgrass interspace was in the exclosures followed in deceasing order by the deferred-rotation; moderately stocked, continuously grazed; HILF; and heavily stocked, continuously grazed pastures. The shortgrass interspace was found often in the heavily stocked, continuously grazed pastures and least in the exclosures. This seral stage of the exclosures was high enough that shortgrass interspace was not present. The differences observed in shrub canopy between grazing treatments were probably the result of original brush control efficiency.

When the range was in good condition, the shrub zonal community occurred in a midgrass community matrix. Shrub zonal and shortgrass communities were located in a midgrass matrix when the range was in good to fair condition. When the range was in fair to poor condition shrub zonal and midgrass communities were found in a shortgrass matrix. 


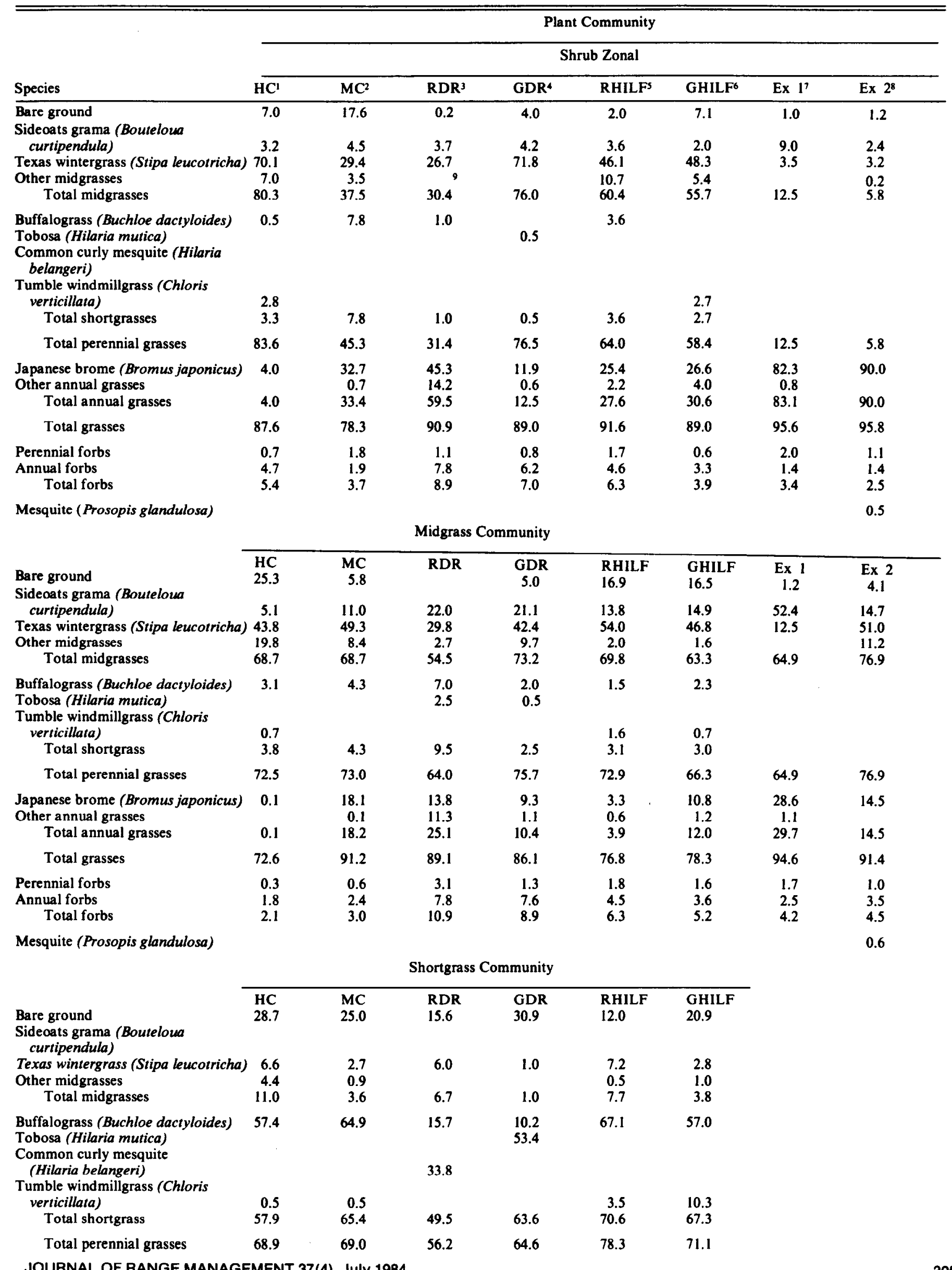


Table 2. (Continued) Mean crown cover (\%) for each species in each plant community and grazing treatment.

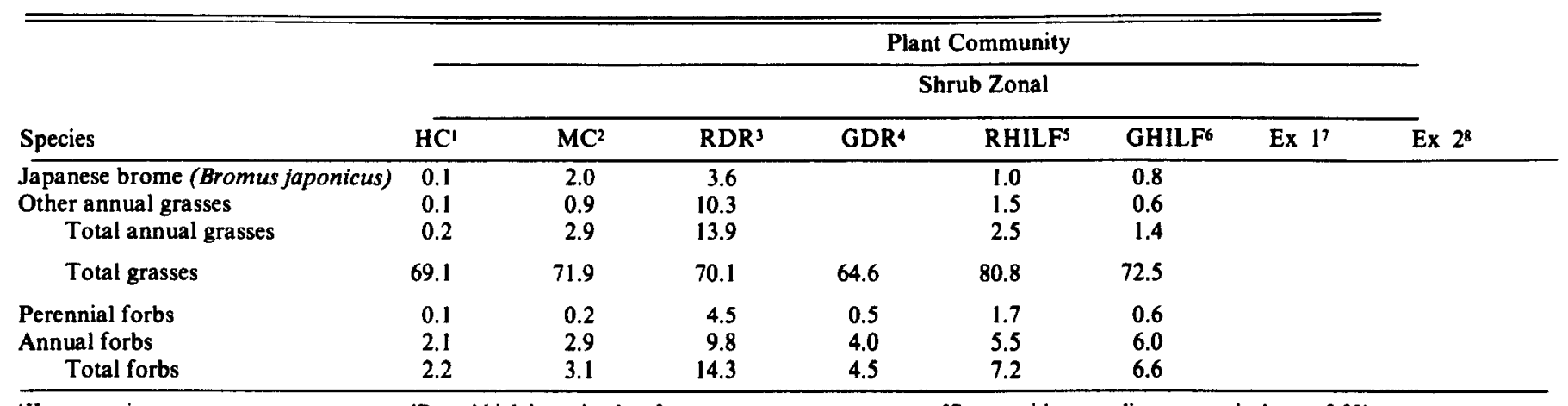

I Heavy continuous

2Moderate continuous

${ }^{3}$ Rested deferred rotation

¿Grazed deferred rotation

\section{Cover}

Crown cover in the shrub zonal community was similar and high in all treatments except for the moderately-stocked, continuouslygrazed treatment (Table 2 ). The smaller crown cover $(82.4 \%$ ) in this treatment may be the result of shading from the overstory. The leaf-area-index of shrubs in this treatment appeared to be greater than in other treatments although it was not quantitatively measured. A high leaf-area-index would also result in more mulch. Crown cover of grasses and forbs averaged across grazing treatments was $95 \%$. The cover of forbs was similar between grazing treatments with a mean of $5.2 \%$. Crown cover of annual grasses in the shrub zonal community appeared to be very responsive to grazing. The lowest value occurred in the heavly-stocked, continuously-grazed pasture and the grazed deferred rotation pasture while annual grass cover in the rested deferred rotation pasture was $59.5 \%$. The highest percentage cover of annual grasses occurred in the exclosures. Perennial grass cover in each treatment was inversely proportional to annual grass values. Perennial grasses in the shrub zonal areas require soil moisture for many months of each year and must compete with the shrub. Annual grasses do not compete as strongly with the shrub because of their shorter life span and they grow when soil moisture levels are in excess of that needed by the shrubs and when the shrubs are dominant. Many annual grasses are favored by a thick mulch layer which occurs in the shrub zonal community.

Texas wintergrass was the dominant perennial grass species and Japanese brome was the dominant annual species in the shrub zonal areas. Silverleaf nightshade occurred in every treatment while Texas broomweed, southwestern carrot, redseed plantain (Plantago rhodosperma), and thistle (Cirsium texanum) occurred in many treatments.

Crown cover values in the midgrass community by grazing treatment occurred in 2 groups. Cover values exceeded $94 \%$ and were similar in the moderately stocked, continuously grazed; deferred-rotation; and exclosure treatments. The heavily stocked, continuously grazed and HILF treatments had cover values between 74 and $84 \%$, were similar to each other, and different from the first group. For all grazing treatments combined, the mean crown cover was $90.6 \%$. Percentage crown covers of forbs differed little among grazing treatments but those in the deferred rotation systems were greatest. Annual grass cover was nearly nonexistent in the heavily stocked, continuously grazed pasture. Although relationships between treatments in this community were similar to those in the shrub zonal community for annual grass crown cover, the magnitudes were much lower. Perennial grass cover was very similar with a range of 64.0 to $76.9 \%$ and a mean of $70.7 \%$. Although different grazing practices may affect grass production and species composition, crown cover was similar among treatments.

Texas wintergrass was the dominant species in one exclosure, the continuously stocked pastures, and the HILF pastures, with
'Spaces with no readings are equivalent to $0.0 \%$

sideoats grama being a subdominant in each of these treatments. Sideoats grama was dominant in the other exclosure. A much more desirable situation for grazing existed in the deferred-rotation pastures, cool-season Texas wintergrass and the warm-season sideoats grama occurred as codominants. Japanese brome was the annual grass with the higher crown cover while Texas bromeweed (Xanthocephalum texanum), and southwestern carrot (Dacus pusillus), and silverleaf nightshade (Solanum elaeagnifolium) occurred in small amounts in every grazing treatment and exclosure.

For the shortgrass community crown cover values varied between 69.1 and $88.0 \%$, with no pattern except that the highest values occurred in the rested deferred-rotation and rested HILF treatments. Crown cover of forbs was 12.2 to 7.2 except in the rested deferred rotation treatment ( $15 \%$ cover) where species diversity was great with at least 11 species present. Annual grass crown cover was also low ( 0 to $2.9 \%$ ) except in the rested deferred-rotation pastures ( $13.9 \%$ cover) where little barley was abundant. Generally, buffalograss was the dominant perennial with tobosa grass or common curlymesquite grass occasionally being dominant.

\section{Standing Crop}

Grass standing crop was similar in the shrub zonal and midgrass communities across all grazing treatments; however, both of these communities had significantly higher grass standing crop than in the shortgrass community (Table 3). Succession from shortgrasses to midgrasses could increase grass standing crop nearly $200 \%$. Standing crop of grass in midgrass communities was similar to shrub zonal and higher than shortgrass in every grazing treatment except the heavily stocked, continuously grazed where grass standing crop among the 3 communities was different.

Table 3. Mean grass standing crop ( $\mathrm{kg} / \mathrm{ha}$ ) for each plant community by grazing treatment.'

\begin{tabular}{llll}
\hline \hline & \multicolumn{3}{c}{ Plant community } \\
\cline { 2 - 4 } Grazing treatment & Shrub zonal & Midgrass & Shortgrass \\
\hline $\begin{array}{l}\text { Heavily stocked, } \\
\quad \text { continuously grazed }\end{array}$ & $2488 \mathrm{~cd}(\mathrm{z})$ & $1508 \mathrm{~d}(\mathrm{y})$ & $865 \mathrm{~b}(\mathrm{x})$ \\
$\begin{array}{l}\text { Moderately stocked, } \\
\quad \text { continuously grazed }\end{array}$ & $2829 \mathrm{bcd}(\mathrm{z})$ & $3333 \mathrm{abc}(\mathrm{z})$ & $980 \mathrm{ab}(\mathrm{y})$ \\
$\begin{array}{l}\text { Rested deferred-rotation } \\
\text { Grazed deferred-rotation }\end{array}$ & $4480 \mathrm{a}(\mathrm{z})$ & $3865 \mathrm{ab}(\mathrm{z})$ & $1498 \mathrm{a}(\mathrm{y})$ \\
Rested HILF & $3618 \mathrm{abcd}(\mathrm{z})$ & $2894 \mathrm{bc}(\mathrm{z})$ & $582 \mathrm{~b}(\mathrm{y})$ \\
Grazed HILF & $2412 \mathrm{~d}(\mathrm{z})$ & $2437 \mathrm{c}(\mathrm{z})$ & $1020 \mathrm{ab}(\mathrm{y})$ \\
Exclosure 1 & $2692 \mathrm{bcd}(\mathrm{z})$ & $2414 \mathrm{c}(\mathrm{z})$ & $1559 \mathrm{a}(\mathrm{y})$ \\
Exclosure 2 & $4294 \mathrm{ab}(\mathrm{z})$ & $4569 \mathrm{a}(\mathrm{z})$ & - \\
All treatments & $3702 \mathrm{abc}(\mathrm{z})$ & $4243 \mathrm{a} \mathrm{(z)}$ & - \\
\hline
\end{tabular}

1 Means followed by the same letter within each column or in parentheses within each row are not significantly different at the $95 \%$ level.

${ }_{2}$ Mean for shorgrass represents six treatments as no shortgrass community was found in the exclosure. 
Grass standing crop among grazing treatments in the shrub zonal communities could be categorized into 2 groups. The group with the greatest standing crop included the exclosures and deferred-rotation grazing treatments where standing crop ranged from 3,618 to $4,480 \mathrm{~kg} / \mathrm{ha}$. The second group included the HILF and continuously grazed treatments where standing crop of grasses ranged from 2,412 to $2,829 \mathrm{~kg} / \mathrm{ha}$.

In the midgrass communities, grass standing crop among grazing treatments were generally categorized into 3 groups of treatments. Exclosures were highest, heavily stocked continuously grazed pastures lowest, and moderately stocked, and continuously grazed, the deferred-rotation and HILF pastures intermediate.

In the shortgrass communities, grass standing crop varied from 582 to $1,559 \mathrm{~kg} / \mathrm{ha}$ with no apparent patterns or trends in the summer of 1977. The standing crop values do not reflect the herbage producing ability of the pasture but rather hydrologic influences and soil protection.

\section{Mulch}

For all grazing treatments combined, mulch differed significantly among communities (Table 4). Within grazing treatments,

Table 4. Mean mulch (metric tons/ha) for each plant community by graxing treatment.

\begin{tabular}{|c|c|c|c|}
\hline \multirow[b]{2}{*}{ Grazing treatment } & \multicolumn{3}{|c|}{ Plant community } \\
\hline & Shrub zonal & Midgrass & Shortgrass \\
\hline $\begin{array}{l}\text { Heavily stocked, } \\
\text { continuously grazed } \\
\text { Moderately stocked, }\end{array}$ & $11.1 \mathrm{~cd}(\mathrm{z})$ & $1.2 \mathrm{~d}(\mathrm{y})$ & $1.1 \mathrm{a}(\mathrm{y})$ \\
\hline continuously grazed & $17.4 \mathrm{bc}(\mathrm{z})$ & $4.5 \mathrm{bc}(\mathrm{y})$ & 1.8 a $(y)$ \\
\hline Rested deferred-rotation & $10.6 \mathrm{~cd} \mathrm{(z)}$ & $5.1 \mathrm{bc}(\mathrm{y})$ & $1.5 \mathrm{a}(\mathrm{x})$ \\
\hline Grazed deferred-rotation & $19.8 \mathrm{~b}(\mathrm{z})$ & $6.1 \mathrm{~b}(\mathrm{y})$ & $1.7 \mathrm{a}(\mathrm{x})$ \\
\hline Rested HILF & $8.3 \mathrm{~d}(\mathrm{z})$ & $3.2 \mathrm{~cd}(\mathrm{y})$ & $1.4 \mathrm{a}(\mathrm{x})$ \\
\hline Grazed HILF & $11.0 \mathrm{~cd} \mathrm{(z)}$ & $4.5 \mathrm{bc}(\mathrm{y})$ & $2.1 \mathrm{a}(\mathrm{y})$ \\
\hline Exclosure 1 & 27.4 a (z) & $12.2 \mathrm{a}(\mathrm{y})$ & - \\
\hline Exclosure 2 & $20.5 \mathrm{~b}(\mathrm{z})$ & $11.5 \mathrm{a}(\mathrm{y})$ & - \\
\hline All treatments & $15.7(\mathrm{z})$ & $6.1(y)$ & $1.6(x)^{2}$ \\
\hline
\end{tabular}

'Means followed by the same letter within each column or in parentheses within each row are not significantly different at the $95 \%$ level.

2Mean for shortgrass represents six treatments as no shortgrass community was found in the exclosure.

mulch in the shrub zonal community was greater than either the midgrass or shortgrass communities. Amounts of mulch in midgrass community in the continuously grazed and grazed HILF pastures did not differ significantly from mulch in the shortgrass community. Conversely, in the deferred-rotation and rested HILF pastures the amount of mulch in the midgrass community was greater than in shortgrass communities. The magnitude of difference between midgrass and shortgrass mulch was one and a half times greater in the deferred-rotation pastures than in the HILF pastures which suggests a better range condition in the deferredrotation pastures.

The amount of mulch in the midgrass community was about 10 times greater in the exclosures than in the heavily stocked continuously grazed pasture. Mulch accumulation in the deferred-rotation pasture was one and a half times greater than on the HILF pastures. Shortgrass community mulch accumulation did not differ significantly among grazing treatments. Low amounts of mulch were an inherent characteristic of this low growing, sod-forming community.

\section{Edaphic}

Soil organic matter content did not differ significantly among plant communities when averaged across grazing treatments (Table 5). Soil organic matter content among plant communities within grazing treatments generally differed little.

Water stable aggregates were not different among plant communities for all grazing treatments combined, nor generally differ-
Table 5. Mean organic content (\%) of soils from each plant community by grazing treatment. ${ }^{1}$

\begin{tabular}{llll}
\hline \hline & \multicolumn{3}{c}{ Plant community } \\
\cline { 3 - 4 } Grazing treatment & Shrub zonal & Midgrass & Shortgrass \\
\hline $\begin{array}{l}\text { Heavily stocked, } \\
\quad \text { continuously grazed }\end{array}$ & $3.6 \mathrm{~cd}(\mathrm{z})$ & $2.6 \mathrm{c}(\mathrm{y})$ & $2.5 \mathrm{~d}(\mathrm{y})$ \\
$\begin{array}{l}\text { Moderately stocked, } \\
\quad \text { continuously grazed }\end{array}$ & $3.0 \mathrm{~d}(\mathrm{y})$ & $3.7 \mathrm{~b}(\mathrm{z})$ & $3.3 \mathrm{c}(\mathrm{yz})$ \\
Rested deferred-rotation & $6.0 \mathrm{a}(\mathrm{z})$ & $5.5 \mathrm{a}(\mathrm{yz})$ & $5.1 \mathrm{a} \mathrm{(y)}$ \\
Grazed deferred-rotation & $4.0 \mathrm{bc}(\mathrm{z})$ & $4.1 \mathrm{~b}(\mathrm{z})$ & $3.9 \mathrm{bc}(\mathrm{z})$ \\
Rested HILF & $4.4 \mathrm{~b}(\mathrm{z})$ & $4.3 \mathrm{~b}(\mathrm{z})$ & $4.1 \mathrm{~b}(\mathrm{z})$ \\
Grazed HILF & $3.7 \mathrm{~cd}(\mathrm{z})$ & $3.5 \mathrm{~b}(\mathrm{z})$ & $3.4 \mathrm{c} \mathrm{(z)}$ \\
Exclosure I & $4.5 \mathrm{~b}(\mathrm{z})$ & $4.3 \mathrm{~b}(\mathrm{z})$ & - \\
Exclosure 2 & $3.3 \mathrm{~d}(\mathrm{z})$ & $2.3 \mathrm{c}(\mathrm{y})$ & - \\
All treatments & $4.9(\mathrm{z})$ & $3.8(\mathrm{z})$ & $3.7(\mathrm{z})$ \\
\hline
\end{tabular}

'Means followed by the same letter within each column or in parentheses within each row are not significantly different at the $95 \%$ level.

${ }_{2}$ Mean for shortgrass represents six treatments as no shortgrass community was found in the exclosure.

ent among plant communities within grazing treatments (Table 6). However, grazing treatments had a significant effect on aggregate stability within each plant community. In the shrub zonal community large differences occurred even though the understory and soil received some protection from the shrub overstory against grazing treatments. The percentage of water stable aggregates in

\section{Table 6. Water stable aggregates mean (\%) for each plant community by grazing treatment.}

\begin{tabular}{|c|c|c|c|}
\hline \multirow[b]{2}{*}{ Grazing treatment } & \multicolumn{3}{|c|}{ Plant community } \\
\hline & Shrub zonal & Midgrass & Shortgrass \\
\hline $\begin{array}{l}\text { Heavily stocked, } \\
\text { continuously grazed } \\
\text { Moderately stocked, }\end{array}$ & $33.9 \mathrm{~d}(\mathrm{z})$ & $35.2 \mathrm{~d}(\mathrm{z})$ & $37.7 \mathrm{c}(\mathrm{z})$ \\
\hline continuously grazed & $51.2 \mathrm{abc}(\mathrm{z})$ & 47.7 bc (z) & $46.2 \mathrm{bc}(\mathrm{z})$ \\
\hline Rested deferred-rotation & 60.1 a (z) & 57.1 ab (z) & $50.1 \mathrm{ab}(\mathrm{z})$ \\
\hline Grazed deferred-rotation & $53.8 \mathrm{ab}(\mathrm{z})$ & $55.7 \mathrm{ab}(\mathrm{z})$ & $56.3 \mathrm{a} \mathrm{(z)}$ \\
\hline Rested HILF & $48.8 \mathrm{abc}(\mathrm{y})$ & 60.5 a (z) & $53.3 \mathrm{ab}(\mathrm{yz})$ \\
\hline Grazed HILF & $42.5 \operatorname{bcd}(z)$ & $44.9 c(z)$ & $40.3 \mathrm{c}(\mathrm{z})$ \\
\hline Exclosure 1 & $54.5 \mathrm{a}(\mathrm{y})$ & 61.5 a (z) & - \\
\hline Exclosure 2 & $41.9 \mathrm{~cd}(\mathrm{z})$ & $39.0 \mathrm{~cd} \mathrm{(z)}$ & - \\
\hline All treatments & $48.2(z)$ & $50.2(\mathrm{z})$ & $47.3(\mathrm{z})^{2}$ \\
\hline
\end{tabular}

'Means followed by the same letter within each column or in parentheses within each row are not significantly different at the $95 \%$ level.

${ }_{2}$ Mean for shortgrass represents six treatments as no shortgrass community was found in the exclosure.

the HILF pastures were lower than in the grazed and rested deferred-rotation; exclosure 1; and moderately stocked, continuously grazed treatments. Soil aggregates from the heavily-stocked, continuously-grazed treatment were significantly less stable than from other treatments, except the grazed HILF and exclosure 2.

Midgrass community water stable aggregates in the rested HILF and deferred-rotation pastures were similar to exclosure 1. However, the water stable aggregates in the grazed HILF pasture were similar to, but less than the moderately stocked, continuously grazed pasture.

With all grazing treatments combined bulk density values were similar for soils from midgrass and shortgrass communities but bulk density from those in the shrub zonal community was significantly lower than those of the shortgrass community except those of the rested HILF or those of any of the midgrass community except the moderately stocked pasture (Table 7). This relationship among plant communities generally existed within grazing treatments except for the HILF pasture where bulk densities in the shrub zonal community were similar to the shortgrass community. The HILF grazing treatment encourages grazing and trampling 
Table 7. Mean bulk density $\left(\mathrm{g} / \mathrm{cm}^{3}\right)$ for each plant community by grazing treatment.'

\begin{tabular}{llll}
\hline & \multicolumn{3}{c}{ Plant community } \\
\cline { 2 - 4 } Grazing treatment & Shrub zonal & Midgrass & Shortgrass \\
\hline $\begin{array}{l}\text { Heavily stocked, } \\
\text { continuously grazed }\end{array}$ & $1.7 \mathrm{ab}(\mathrm{y})$ & $1.8 \mathrm{a}(\mathrm{z})$ & $1.9 \mathrm{a}(\mathrm{z})$ \\
$\begin{array}{l}\text { Moderately stocked, } \\
\text { continuously grazed }\end{array}$ & $1.5 \mathrm{c}(\mathrm{y})$ & $1.6 \mathrm{~b}(\mathrm{yz})$ & $1.7 \mathrm{~b}(\mathrm{z})$ \\
Rested deferred-rotation & $1.4 \mathrm{c}(\mathrm{y})$ & $1.6 \mathrm{~b}(\mathrm{z})$ & $1.6 \mathrm{c}(\mathrm{z})$ \\
Grazed deferred-rotation & $1.6 \mathrm{bc}(\mathrm{y})$ & $1.8 \mathrm{a}(\mathrm{z})$ & $1.7 \mathrm{~b}(\mathrm{z})$ \\
Rested HILF & $1.8 \mathrm{a}(\mathrm{y})$ & $1.9 \mathrm{a}(\mathrm{z})$ & $1.8 \mathrm{ab}(\mathrm{yz})$ \\
Grazed HILF & $1.8 \mathrm{a}(\mathrm{y})$ & $1.9 \mathrm{a}(\mathrm{z})$ & $1.9 \mathrm{a}(\mathrm{z})$ \\
Exclosure 1 & $1.0 \mathrm{~d}(\mathrm{y})$ & $1.3 \mathrm{c}(\mathrm{z})$ & - \\
Exclosure 2 & $1.6 \mathrm{bc}(\mathrm{y})$ & $1.8 \mathrm{a}(\mathrm{z})$ & - \\
All treatments & $1.5(\mathrm{y})$ & $1.7(\mathrm{z})$ & $1.8(\mathrm{z})^{2}$ \\
\hline
\end{tabular}

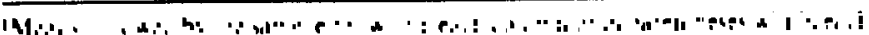

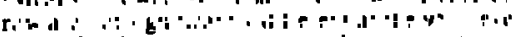

${ }_{2}$ Mean for shortgrass represents six treatments as no shortgrass communty was found in the exclosure.

underneath shrubs as well as in the interspaces, which promotes increased bulk densities.

\section{Literature Cited}

Black, C.A. 1965. Methods of soil analysis. Amer. Soc. Agron. Series. No. 9. Madison, Wis.

Bouyoucos, G.J. 1962. Hydrometer method improved for making particle size analysis of soil. Agron. J. 54:464-465.

Costello, D.V. 1964. Range dynamics control-an ecological urgency. p. 91-107. In: Grazing in Terrestrial and Marine Environments (D.C. Crisp, Editor). Blackwells Scientific Pub. Adlard and son, Ltd., Dorking, Eng.

Driscoll, R.S. 1967. Managing public rangelands: Effective livestock grazing practices and systems for national forests and national grasslands. USDA. AIB-315.
Ellison, L. 1960. Influence of grazing on plant succession of rangelands. Bot. Review 26:1-78.

Gould, F.W. 1975. Texas plants-a checklist and ecologial summary. Texas Agr. Exp. Sta. MP-585/Revised.

Heady, H.F. 1975. Rangeland Management. McGraw-Hill Book Co., Inc. New York, N.Y.

Hickey, W.C., Jr. 1966. A discussion of grazing management systems and some pertinent literature (abstracts and excerpts) 1895-1966. USDA Forest Serv., Denver, Colo.

Kothmann, M.M., W.H. Blackburn, and G. Innis. 1982. The systems approach to grazing management research: concepts and philosophies. In Proceedings: A National Conference on Grazing Management Technology. (D.D. Briske and M.M. Kothmann, Editors). Texas A\&M Univ., College Station.

Kothmann, M.M., J.W. Mathis, P.T. Marion, and W.J. Waldrip. 1970. Livestock production and economic returns from grazing treatments on the Texas Experimental Ranch. Texas Agr. Exp. Sta. B-1100.

Kothmann, M.M., W.J. Waldrip and G.W. Mathis. 1978. Rangeland vegetation of the Texas Rolling Plains: Response to grazing management and weather. Proc. Ist Internat. Rangeland Cong., Soc. Range Manage., Denver, Colo.

Laycock, W.A., and P.W. Conrad. 1967. Effect of grazing on soil compaction as measured by bulk density on a high elevation cattle range. J. Range Manage. 20:136-140.

Levy, E.B., and E.A. Madden. 1933. The point method of pasture analysis. New Zeal. J. Agr. 46:276-279.

Lewis, J.K. 1969. Range management viewed in the ecosystem framework. In: The Ecosystem Concept in Natural Resource Management (G.M. Van Dyne, Editor). Academic Press, New York, N.Y.

Lull, H.W. 1959. Soil compaction on forest and rangelands. USDA Misc. Pub. 758.

McGinty, W.A., F.E. Smeins, and L.B. Merrill. 1979. Influence of soil, vegetation, and grazing management on infiltration rate and sediment production of Edwards Plateau rangeland. J. Range Manage. 32:33-37.

Snedecor, G.W., and W.G. Cochran. 1971. Statistical Methods. Iowa State Univ. Press. Ames.

Steel, R.G.D., and J.H. Torrie. 1960. Principles and Procedures of Statistics. McGraw-Hill Book Co., Inc. New York, N.Y.

\section{HABITAT RESTORATION SCIENTIST}

B.S./B.A. in botanical or ecological sciences plus $5-10$ years additional training and/or experience in the field of habitat restoration. At least 2-3 years of this training/experience must be in a position that was directly involved in practical, applied habitat restoration on a large scale, preferably for an energy related project and must have had more than technical input to the program. Must have demonstrated publication record including senior authorship, plus training in remote sensing in the broadest sense, biostatistics, computer technology, modelling, radiation biology, ecology, techniques, and experience with wildife, especially endangered species desired. Will implement habitat restoration plan at Elk Hills, Kern County, California, design and conduct R\&D programs, assist with botanical and ecological support. Will assist supervisor in developing new programs and provide both oral and written communications with sponsors. Will synthesize literature and research data into professionally acceptable topical reports and articles in refereed, scientific journals.

Qualified candidates send resume to:

EG\&G Energy Measurements, Inc.

Attn: Personnel

P.O. Box 98

Goleta, California 93116

U.S. Citzenship Required

An Equal Opportunity Employe

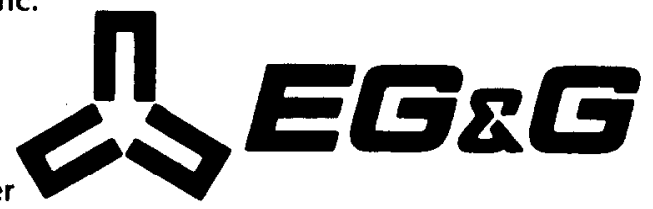

